\title{
Satisfaction Assessment and Burnout of Employees in Some Community Health Centers in City of Samsun
}

\section{Samsun İlindeki Bazı Toplum Sağlığı Merkezi Çalışanlarında Memnuniyet Düzeyi ve Tükenmişlik Durumu}

Onur Öztürk* ${ }^{1}$, Eylem Işık Uyar ${ }^{1}$

\begin{abstract}
Objective: Community health center is the health institution determining related risks and problems in order to protect and improve public health, making corrective and preventive activities and providing the coordination between the health institutions in its area and other institutions and organizations. Satisfaction and burnout of employees in community health centers constitute a serious problem which may disrupt health service providing and receiving stages. In our study, we aimed to discuss the issue. Methods: We reached 163 employees in five community health centers in Samsun. Employee satisfaction survey and Maslach Burnout Inventory were applied. Results: The ratio of women participants was 65.6\%. Nurse-midwife-medical officer group was the most common occupation group (47.9\%). It was observed that our demographic data didn't effect burnout. Emotional burnout and personal success scores were at the worst levels in those participants who had at least nine years of community health center experience and desensitization increased without a statistically significance. Conclusion: It is observed that satisfaction status of participants who work at community health center is higher while burnout is found less than workers in some other health institutions. Positive communication and occupational support provided by management units and managers to the staff may increase the thrust and satisfaction.
\end{abstract}

Key words: Community Health Center, satisfaction, burnout

\section{ÖZET}

Amaç: Toplum sağlığı merkezi; toplumun sağlığını korumak ve geliştirmek maksadıyla, ilgili risk ve sorunları belirleyen, düzeltici ve önleyici faaliyetleri gerçekleştiren, bölgesinde bulunan sağlık kuruluşları ile diğer kurum ve kuruluşlar arasındaki koordinasyonu sağlayan sağlık kuruluşudur. Toplum sağlı̆̆ merkezlerindeki çalışan memnuniyeti ve tükenmişliği, sağlık hizmeti sunma ve alma aşamalarını sekteye uğratabilecek önemli bir problemdir. Çalışmamızda bu konuyu irdelemeyi amaçladık. Gereç ve Yöntem: Samsun ilinde, beş toplum sağlığı merkezinde 163 çalışana ulaşılmıştır. Çalışan memnuniyet anketi ve Maslach Tükenmislik Envanteri uygulanmıştır. Bulgular: Katılımcıların \% 65,6'sı kadındı. Hemşire-ebe-sağlık memuru en sık karşılaşılan meslek grubuydu (\%47,9). Demografik verilerimizin tükenmişliği etkilemediği görülmüştür. Dokuz yıl ve üzeri toplum sağlığı merkezi deneyimi olan katılımcılarda duygusal tükenme ve kişisel başarının skorlarının en kötü düzeylerde olduğu, duyarsızlaşmanın ise istatistiki anlam ifade etmeksizin arttığı görülmüştür. Sonuç: Toplum sağlığı merkezi çalışanı katılımcılarda, diğer bazı sağlık kuruluşlarında çalışanlarla kıyaslandığında memnuniyet durumunun daha yüksek, tükenmişliğin ise daha az olduğu görülmüştür. İdari birimlerin ve yöneticilerin personelle kurduğu pozitif iletişim ve çalışma desteğinin, iş yerindeki güven ortamını ve memnuniyeti arttırabileceği sonucuna varılmıştır.

Anahtar kelimeler: Toplum Sağlı̆̆ Merkezi, memnuniyet, tükenmişlik

Received / Geliș tarihi: 27.11.2015, Accepted / Kabul tarihi: 18.10 .2016

${ }^{1}$ Atakum Toplum Sağllğ̆ Merkezi

*Address for Correspondence / Yazışma Adresi: Onur Öztürk, Atakum Toplum Sağlığı Merkezi,Samsun-TÜRKIYE, E-mail: dr.onurozturk@ yahoo.com Öztürk O, Uyar EI. Samsun İlindeki Bazı Toplum Sağlığı Merkezi Çalışanlarında Memnuniyet Düzeyi ve Tükenmişlik Durumu. TJFMPC, 2016;10(4): 213221.

DOI: $10.21763 /$ tjfmpc.271092 


\section{GíRIŞ}

Toplum sağlı̆̆ bölgesinde yaşayan toplumun sağlığını korumak ve geliştirmek maksadıyla, ilgili risk ve sorunları belirleyen, düzeltici ve önleyici faaliyetleri gerçekleştiren; birinci basamak koruyucu, iyileştirici ve rehabilite edici sağlık hizmetlerini koordine eden ve bu hizmetlerin etkin ve verimli bir şekilde sunulmasını izleyen, değerlendiren, denetleyen ve destekleyen; bölgesinde bulunan sağlık kuruluşları ile diğer kurum ve kuruluşlar arasındaki koordinasyonu sağlayan sağlık kuruluşudur. ${ }^{1}$ TSM'de görev yapan ekip; hekimler, sağlık memurları, hemşireler ve diğer sağlık personelinden oluşan geniş bir kadroya sahiptir.

Çalışan memnuniyeti, çalışanların yaşamlarında önemli kabul ettikleri şeyleri, yaptıkları işlerinden ne oranda elde ettiklerine ilişkin algılarının bir çıktısıdır. Yani çalışanın işi ve iş çevresinden beklentilerinin karşılanma düzeyine göre gösterdiği hoşnutluk veya hoşnutsuzluk, onun memnuniyeti ya da memnuniyetsizliğidir. ${ }^{2}$ Çalışan için iş, tam gün çalışmada gününün minimum sekiz saatini ve yaklaşık yaşamının 25-30 yılını kapsamaktadır. Durum böyleyken, çalışanın işinden memnun olması, aslında hayatından memnun olması için bir basamaktır. Çalışan memnuniyetine etki eden yaş, cinsiyet, statü gibi bireysel ve çalışma koşulları, ortam, birlikte çalışılan kişiler gibi kurumsal faktörler vardır.

Maslach; tükenmişliğin bireyin sahip olduğu değerlerde, itibarda ve maneviyatta bir aşınmayı temsil ettiğini, en yalın haliyle tükenmişliğin insan ruhunun çöküşü olduğunu vurgulamakta, yavaş, yavaş ve sürekli olarak gelişen, insanı, kurtuluşu zor bir girdabın içine sürükleyen bir hastalık olarak ifade etmektedir. Cinsiyet, eğitim düzeyi, yaş ve çalışmışlık süresi gibi çeşitli faktörler tükenmişlik ile ilişkili görünmektedir. ${ }^{3}$ Tükenmişlik kavramı; tükenmişliği yaşayan bireyin yaşamında gerçekleşen değişimleri ifade eden duygusal tükenme, duyarsızlaşma ve kişisel başarıya ilişkin duyguları kategorize eden üç ayrı boyutta ele alınmaktadır. Duygusal tükenme bileşeni, tükenmişliğin en temel boyutu ve en net belirtisi olarak kabul edilmektedir. ${ }^{4}$ Duyarsızlaşma bileşeni, tükenmişliğin kişiler arası boyutunu temsil etmektedir. Kişisel başarı bileşeni ise, kişinin kendisini olumsuz değerlendirme eğiliminde olmasinı ifade eder. ${ }^{5}$

Son y1llarda hasta memnuniyeti üzerine bir çok çalışma yapılmış olsa da, çalışan memnuniyeti üzerine yapılmış bilimsel çalışma oldukça azdır. Hele ki TSM çalışanlarına odaklanarak hazırlanmış akademik çalışmalara pek rastlanmamaktadır. Bu bakımdan çalışmamızın bilime katkı sağlayacağına inanılmaktadır.

\section{YÖNTEM}

Araştırmamız, kesitsel bir anket çalışmasıdır. Samsun ilindeki TSM'ler evreni oluşturmaktadır. Demografik verilerin yanında, memnuniyeti ve tükenmişliği değerlendiren iki anket kullanılmıştır. Anketler Mayıs-Ağustos 2015 tarihleri arasında, seçkisiz olmayan örnekleme yöntemlerinden uygun örnekleme ile belirlenen beş TSM'de, TSM başkanlarının izni ile, çalışanların (n=181) \%90'ını oluşturan gönüllüler tarafindan doldurulmuş, kişi başı ortalama 20 dakika sürmüştür. Toplam 163 kişiye ulaşılmıştır.

Memnuniyet anketi, "T.C Sağlık Bakanlığının Memnuniyet Anketleri Uygulama Rehberi"'nden edinilen, çalışan memnuniyet anketinden TSM personeline göre uyarlanmıştır. ${ }^{6}$ Beşi demografik verileri sorgulayan, 26's1 TSM'deki iş yükü, deneyim, çalışanlar ve yöneticiler arası ilişkiyi değerlendiren, toplam 31 sorudan oluşmaktadır. Maslach ve Jackson tarafından geliştirilen, Maslach Tükenmislik Envanteri, 22 maddeden oluşan 7'li likert tipi bir ölçektir. Özgün formunda, "hiçbir zaman, yılda birkaç kere, ayda bir, ayda birkaç kere, haftada bir, haftada birkaç kere, her gün" şeklindeki cevap seçeneklerinden oluşmaktadır. Duygusal Tükenme, Duyarsızlaşma ve Kişisel Başarı olmak üzere 3 alt boyutu kapsamaktadır. Duygusal Tükenme 9 maddeden, duyarsızlaşma 5 maddeden, kişisel basarı 8 maddeden oluşmaktadır. Ergin; uyarlama çalışmasında, doktor, hemşire, öğretmen, avukat, polis ve memurlardan oluşan 235 kişilik bir çalışma grubuna ön uygulama yaparak ölçekte bazı değişiklikler yapmıştır. Ölçekte yedi dereceli olan cevap seçenekleri "hiçbir zaman, çok nadir, bazen, çoğu zaman ve her zaman olmak üzere beşli derecelendirmeye dönüştürülmüştür. Bizim çalışmamızda da 5'li likert tipi kullanılmıştır. Alt boyutların her bir maddesi 0-4 arasındaki sayılarla puanlanmaktadır. Tükenmişliğin yüksekliği duygusal tükenme ve duyarsızlaşma alt ölçeklerindeki yüksek puanı, kişisel başarı alt ölçeğindeki düşük puanı yansıtmaktadır. Puanlamada, her bir kişi için üç ayrı tükenmişlik puanı hesaplanmaktadır.

İstatistiklerde, SPSS 20.0 paket programı kullanılmıştır. Bulguların tanımlanmasında sıklık değerleri, medyan ve aritmetik ortalama, nitel verilerin karşılaştırılmasında ki-kare ve iki değişkenli korelasyon çalışılmıştır. P değeri, yüzde 5 'in altında olduğu durumlarda ilişki anlamlı kabul edilmiştir. Bu çalışma için Samsun Halk Sağlı̆̆ Müdürlüğü'nden gerekli izin alınmış, Ondokuz Mayıs Üniversitesi Klinik Araştırmalar Etik 
Kurulu'ndan 04.05.2015 tarihinde etik onay alınmıştır.

\section{BULGULAR}

Samsun ilinden, araştırmamıza dahil olan beş TSM'nin verilerine göre;

Katılımcıların ( $\mathrm{n}=163) \%$ 65,6'i kadın, \% 34,4'ü erkekti. 38-47 yaş aralığında daha çok çalışan vardı (\% 42,3). Hemşire-ebe-sağlık memuru (H-E-SM) en sık karşılaşılan meslek grubuydu $(\% 47,9)$, aynı kurumda 7- 9 yıldır çalışanlar $(\% 27,0)$ ve üniversite mezunu olanlar $(\% 41,1)$ ağırlıktaydı (Tablo 1).

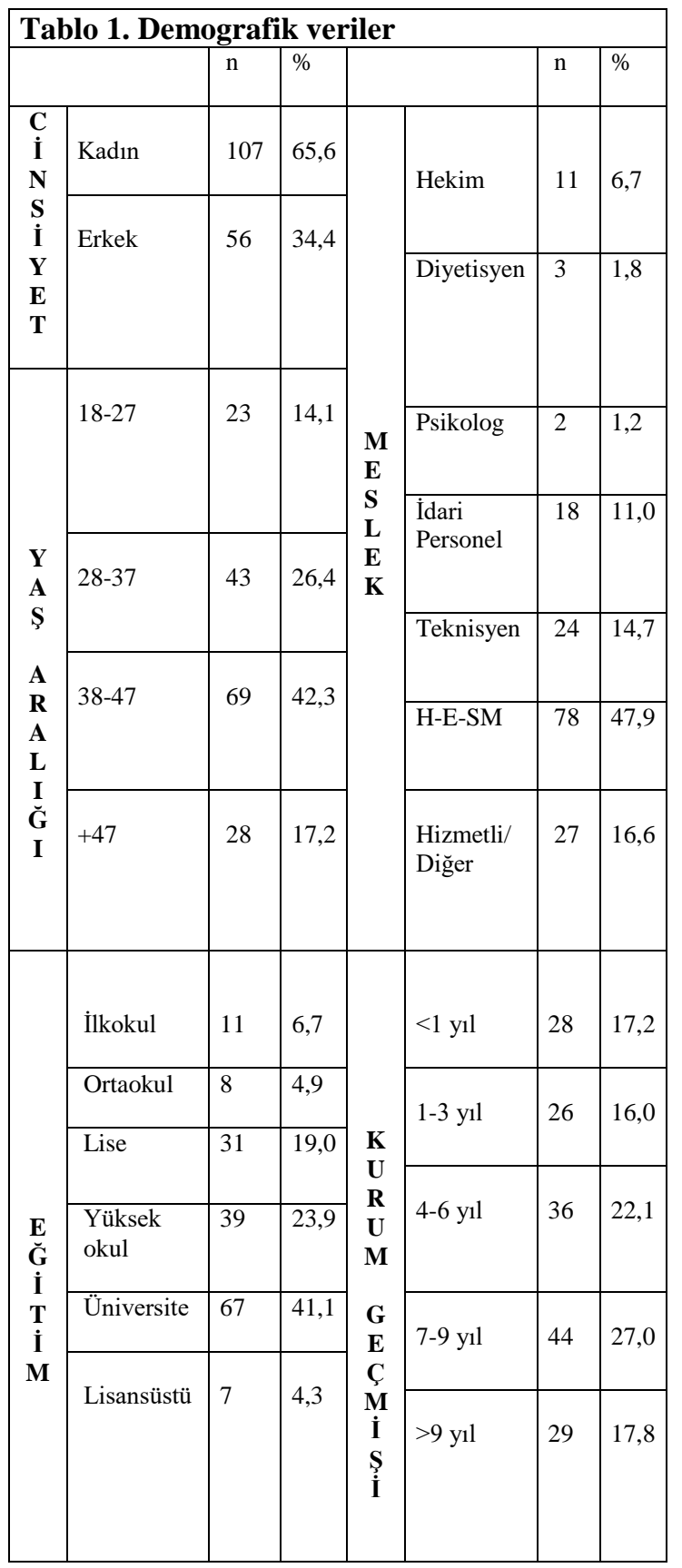

'TSM'de çalışmaktan memnun musunuz' sorusuna $\% 88,9$ oranında olumlu cevap verilmiştir. Fakat çalışma hayatıyla ilgili tükenmişlik yaşadığını düşünenlerin oranı \%67,7 idi. Yaptığ 1 işten mesleki olarak tatmin olanların oranı $\% 59,1$ 'dir. Personelin \%27,8'i, yapılan eğitimleri yeterli bulmamaktadır. (Tablo 2-a) Aktif çalışma yüzdesi ortalaması $70,9 \pm 21,1$ olarak hesaplanmıştır. Bir işi tek başına yapmaktan hoşlananların oranı ise $\% 45,5$ olarak saptanmıştır. Çalışanların çoğu $(\% 40,1)$, işle ilgili bir probleme arkadaşları ile çözüm üretmektedir. (Tablo 2-b)

"İdari birimler işlerinizin yapılması konusunda ne kadar ilgili" sorusuna olumlu cevap verenlerde, tükenmişlik hissi daha az bulunmuştur $(\mathrm{p}<0,001, r=-0,26)$. Buna paralel olarak, TSM'de çalışmaktan memnun olanlarda da tükenmişlik hissi daha azdır $(p<0,001)$ ve bu kişilerde işe severek ve isteyerek gelme eylemi, kuvvetli bir pozitif korelasyon göstermektedir $(\mathrm{p}<0,001, \mathrm{r}=0,70)$. Yönetimden, yeterli katkıyı alanlarda memnuniyet daha yüksek bulunmuştur $(\mathrm{p}<0,001, \mathrm{r}=0,25)$, bu kişilerde tükenmişlik de daha az hissedilmektedir $(\mathrm{p}<0,001, r=-0,26)$. Yeniliklere aç1k olanlarda ise, tükenmişlik daha düşük bulunmuştur $(\mathrm{p}=0,02, \mathrm{r}=-$ 0,18 ). Çalışanlar arasındaki güven ortamının sağlanması da, tükenmişliği azaltan faktörler arasında bulunmuştur $(\mathrm{p}<0,001, \mathrm{r}=-0,25)$. (Tablo 3) Duygusal tükenme alt ölçeğine göre, en çok tükenmişlik gösteren yaş aralığı $28-37$ ve $38-47$ (medyan 10.00), en çok tükenmişlik gösteren eğitim düzeyi ilkokul (medyan 14.00), en çok tükenmişlik gösteren cinsiyet erkek (medyan 10.00), meslek grubu ise diyetisyen (medyan 17.50) olarak saptanmıştır. Duyarsızlaşma alt ölçeğine göre, en çok tükenmişlik gösteren yaş aralığ 18-27 ve 48-57 (medyan 4.50), en çok tükenmişlik gösteren eğitim düzeyi yüksek lisans ve üstü (medyan 5.00), en çok tükenmişlik gösteren cinsiyet erkek (medyan 4.00), meslek grubu ise psikolog (medyan 6.50) olarak saptanmıştır. Kişisel başarı alt ölçeğine göre, en çok tükenmişlik gösteren yaş aralığı 38-47 ve 48-57 (medyan 10.00), en çok tükenmişlik gösteren eğitim düzeyi ortaokul (medyan 5.50), en çok tükenmişlik gösteren cinsiyet erkek (medyan 10.00), meslek ise hizmetli/diğer (medyan 8.50) olarak saptanmıştır. (Tablo 4) Maslach tükenmişlik ölçeğinin, üç alt ölçeğini, yaş, eğitim, cinsiyet, meslek, TSM'de çalışmışlık süresi ve aktif çalışma ile karşılaştırdığımızda, gerek duygusal tükenmede, gerekse de duyarsızlaşma ve kişisel başarıda herhangi bir fark bulunmamıştır. (Tablo 5)

Duygusal tükenme alt ölçeğine göre; yaptığ 1 işten tatmin olmayanlarda tükenmişlik daha fazladır (medyan 11.00). Çalışma hayatında tükenmişlik yaşadığını düşünenlerde, tükenmişlik daha fazladır (medyan 14.00). Kurumunda, 


\begin{tabular}{|c|c|c|c|}
\hline Sorular & Olumlu \% & $\begin{array}{c}\text { Orta } \\
\text { Düzey } \%\end{array}$ & $\underset{\%}{\text { Olumsuz }}$ \\
\hline $\begin{array}{l}\text { Yönetim açısından ne kadar } \\
\text { memnunsunuz? }\end{array}$ & 82,2 & 8,6 & 9,2 \\
\hline $\begin{array}{l}\text { Bir üst amirinize sorunlarınız için } \\
\text { başvuruyor musunuz? }\end{array}$ & 88,8 & & 11,2 \\
\hline $\begin{array}{l}\text { Sorunlarınız için yeterli katkıyı alıyor } \\
\text { musunuz? }\end{array}$ & 77,2 & & 22,8 \\
\hline TSM'de çalışmaktan memnun musunuz? & 88,9 & & 11,1 \\
\hline $\begin{array}{l}\text { TSM'ye severek ve isteyerek geliyor } \\
\text { musunuz? }\end{array}$ & 87,5 & & 12,5 \\
\hline Yaptığınız işi seviyor musunuz? & 89,3 & & 10,7 \\
\hline $\begin{array}{l}\text { Yaptığınız iş sizi mesleki olarak tatmin } \\
\text { ediyor mu? }\end{array}$ & 59,1 & & 40,9 \\
\hline Yaptığınız işin yetkisi size veriliyor mu? & 71,2 & 20,0 & 8,8 \\
\hline $\begin{array}{l}\text { Kurumunuzda yapmış olduğunuz isle } \\
\text { ilgili yeterli } \\
\text { düşünüyor musunuz? }\end{array}$ & 77,0 & 16,1 & 6,8 \\
\hline $\begin{array}{l}\text { Yapilan eğitimleri yeterli buluyor } \\
\text { musunuz? }\end{array}$ & 53,8 & 18,4 & 27,8 \\
\hline $\begin{array}{l}\text { İsinizi yaparken } \\
\text { yapıyor musunuz? }\end{array}$ & 83,0 & & 17,0 \\
\hline İsinizle ilgili yeniliklere açık misiniz? & 96,9 & & 3,1 \\
\hline $\begin{array}{l}\text { İsinizle ilgili etkinliklere/eğitimlere } \\
\text { katılıyor musunuz? }\end{array}$ & 78,2 & & 21,8 \\
\hline $\begin{array}{l}\text { Çalışma hayatında kendinizi başkalarıyla } \\
\text { kıyaslıyor musunuz? }\end{array}$ & 25,0 & & 75,0 \\
\hline $\begin{array}{l}\text { Çalıştığınız birimlerdeki diğer personeller } \\
\text { ile iletişiminizi değerlendirir misiniz? }\end{array}$ & 62,9 & 35,2 & 1,9 \\
\hline $\begin{array}{l}\text { Sizce is arkadaşınızın bir problemle ilgili } \\
\text { yöneticiye danışarak çözüm üretmesi } \\
\text { ispiyonlamak mıdır? }\end{array}$ & 13,4 & & 86,6 \\
\hline $\begin{array}{l}\text { İdari birimler islerinizin } \text { yapılması } \\
\text { konusunda ne kadar ilgili? }\end{array}$ & 69,9 & 28,3 & 1,8 \\
\hline $\begin{array}{l}\text { Çalışma hayatıyla ilgili tükenmişlik } \\
\text { yaşadığınızı düşünüyor musunuz? }\end{array}$ & 32,3 & & 67,7 \\
\hline $\begin{array}{l}\text { Kurumunuzda karşılıklı güven ortamı } \\
\text { içerisinde çalıștığınıza inanıyor musunuz? }\end{array}$ & 59,2 & 21,7 & 19,1 \\
\hline $\begin{array}{l}\text { Yaptığınız işle ilgili görev tanımlamanızı } \\
\text { biliyor musunuz? }\end{array}$ & 84,1 & 14,6 & 1,3 \\
\hline
\end{tabular}

Tablo 2-b. Memnuniyet anketine verilen cevaplar-2

\begin{tabular}{|c|c|c|}
\hline Sorular & Şıklar & Cevaplar (\%) \\
\hline \multirow{3}{*}{$\begin{array}{l}\text { Bir mesai gününün yüzde kaçını işle } \\
\text { ilgili çalışmalar yaparak } \\
\text { geçiriyorsunuz? }\end{array}$} & a) $\% 0-50$ & 19,9 \\
\hline & b) $\quad \% 51-70$ & 12,4 \\
\hline & c) $\% 71-100$ & 67,7 \\
\hline \multirow{2}{*}{ Bir işi yaparken; } & a) Tek başıma yapmaktan hoşlanırım & 45,5 \\
\hline & b) Diğer arkadaşlarımla birlikte yapmaktan hoşlanırım & 54,5 \\
\hline \multirow{4}{*}{$\begin{array}{l}\text { İşinizle ilgili bir problem olduğunda } \\
\text { nasıl bir çözüm yöntemi } \\
\text { geliştirirsiniz? }\end{array}$} & a) Kendim çözerim & 19,7 \\
\hline & b) Yöneticiyle beraber çözüm üretirim & 38,9 \\
\hline & c) Arkadaşımla beraber çözüm üretirim & 40,1 \\
\hline & d) Beklerim zaman içinde kendiliğinden çözümlenir & 1,3 \\
\hline
\end{tabular}




\begin{tabular}{|c|c|c|c|c|}
\hline \multirow[t]{2}{*}{ Sorular } & \multicolumn{2}{|c|}{$\begin{array}{l}\text { TSM'ye severek ve isteyerek } \\
\text { geliyor musunuz? }\end{array}$} & \multicolumn{2}{|c|}{$\begin{array}{l}\text { Çalışma hayatıyla ilgili tükenmişlik } \\
\text { yaşadığınızı düşünüyor musunuz? }\end{array}$} \\
\hline & p değeri & r değeri & p değeri & r değeri \\
\hline $\begin{array}{l}\text { Yönetim açısından ne } \\
\text { kadar memnunsunuz? }\end{array}$ & $<0,001$ & 0,33 & 0,07 & $-0,16$ \\
\hline $\begin{array}{l}\text { Bir üst amirinize } \\
\text { sorunlarınız için } \\
\text { başvuruyor musunuz? }\end{array}$ & 0,05 & 0,16 & 0,39 & $-0,08$ \\
\hline $\begin{array}{l}\text { Sorunlarınız için } \\
\text { yeterli katkıyı alıyor } \\
\text { musunuz? }\end{array}$ & $<0,001$ & 0,35 & $<0,001$ & $-0,24$ \\
\hline $\begin{array}{l}\text { TSM'de çalışmaktan } \\
\text { memnun musunuz? }\end{array}$ & $<0,001$ & 0,70 & $<0,001$ & $-0,32$ \\
\hline $\begin{array}{l}\text { TSM'ye severek ve } \\
\text { isteyerek geliyor musunuz? }\end{array}$ & $\begin{array}{c}\text { IIIIIIIIIIIIIIIIIIIIIIIIIII } \\
\text { IIIIIIIIIIIII }\end{array}$ & $\begin{array}{l}\text { IIIIIIIIIIIIIIIIIIII } \\
\text { IIIIIIIIIIIIIIIIIIII } \\
\text { /I }\end{array}$ & $<0,001$ & $-0,33$ \\
\hline $\begin{array}{l}\text { Yaptığınız işi seviyor } \\
\text { musunuz? }\end{array}$ & $<0,001$ & 0,54 & $<0,001$ & $-0,31$ \\
\hline $\begin{array}{l}\text { Yaptığınız iş sizi mesleki } \\
\text { olarak tatmin ediyor mu? }\end{array}$ & $<0,001$ & 0,33 & $<0,001$ & $-0,25$ \\
\hline $\begin{array}{l}\text { Yaptığınız işin yetkisi size } \\
\text { veriliyor mu? }\end{array}$ & 0,23 & 0,06 & 0,09 & $-0,15$ \\
\hline $\begin{array}{l}\text { Kurumunuzda yapmış } \\
\text { olduğunuz isle ilgili } \\
\text { yeterli katkıyı verdiğinizi } \\
\text { düşünüyor musunuz? }\end{array}$ & 0,66 & 0,05 & 0,55 & $-0,05$ \\
\hline $\begin{array}{l}\text { Yapılan eğitimleri yeterli } \\
\text { buluyor musunuz? }\end{array}$ & $<0,001$ & 0,24 & 0,11 & $-0,02$ \\
\hline $\begin{array}{l}\text { İsinizi yaparken zaman } \\
\text { planlaması } \\
\text { yapıyor musunuz? }\end{array}$ & 0,05 & 0,17 & 0,81 & $-0,02$ \\
\hline $\begin{array}{l}\text { İsinizle ilgili yeniliklere } \\
\text { açı misiniz? }\end{array}$ & 0,49 & 0,04 & 0,03 & $-0,18$ \\
\hline $\begin{array}{l}\text { İsinizle ilgili etkinliklere/ } \\
\text { eğitimlere } \\
\text { katılıyor musunuz? }\end{array}$ & 0,24 & 0,09 & 1.00 & 0,01 \\
\hline $\begin{array}{l}\text { Çalışma hayatında kendinizi başkalarıyla } \\
\text { kıyaslıyor musunuz? }\end{array}$ & 0,58 & $-0,04$ & 0,69 & 0,04 \\
\hline $\begin{array}{l}\text { Çalıştığınız birimlerdeki diğer personeller ile } \\
\text { İletişiminizi değerlendirir misiniz? }\end{array}$ & 0,86 & $-0,01$ & 0,68 & 0,04 \\
\hline $\begin{array}{l}\text { Sizce is arkadaşınızın bir problemle ilgili yöneticiye } \\
\text { danışarak çözüm üretmesi ispiyonlamak mıdır? }\end{array}$ & 0,73 & $-0,01$ & 0,07 & 0,15 \\
\hline $\begin{array}{l}\text { İdari birimler islerinizin yapılması konusunda } \\
\text { ne kadar ilgili? }\end{array}$ & $<0,001$ & 0,25 & $<0,001$ & $-0,26$ \\
\hline $\begin{array}{l}\text { Çalışma hayatıyla ilgili tükenmişlik yaşadığınızı } \\
\text { düşünüyor musunuz? }\end{array}$ & $<0,001$ & $-0,33$ & 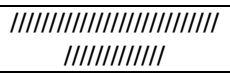 & 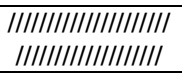 \\
\hline $\begin{array}{l}\text { Kurumunuzda karşılıklı güven ortamı içerisinde } \\
\text { çalıştığınıza inanıor musunuz? }\end{array}$ & $<0,001$ & 0,29 & $<0,001$ & $-0,25$ \\
\hline $\begin{array}{l}\text { Yaptığınız işle ilgili görev tanımlamanızı } \\
\text { biliyor musunuz? }\end{array}$ & 0,20 & 0,08 & 0,46 & $-0,09$ \\
\hline
\end{tabular}

karşılıklı güven ortamı içerisinde çalıştığına inanmayanlarda tükenmişlik daha fazladır (medyan 13.00). TSM'de çalışmışlık deneyimine göre ise 4 yıl ve üzeri çalışanlarda tükenmişlik en yüksek değerdedir (medyan 10,00). Duyarsızlaşma alt ölçeğine göre; yaptığı işten tatmin olmayanlarda tükenmişlik daha fazladır (medyan 4.00). Çalışma hayatında, tükenmişlik yaşadığını düşünenlerde tükenmişlik daha fazladır (medyan 5.00). Kurumunda, karşılıklı güven ortamı içerisinde çalıştığına inanmayanlarda tükenmişlik daha fazladır (medyan 6.00). TSM'de çalışmışlık deneyimine göre ise $<1$ yıl ve 7-9 yıl çalışanlarda tükenmişlik daha fazladır (medyan 4,00). Kişisel başarı alt ölçeğine göre; ilginç olarak yaptığı işten tatmin olanlarda tükenmişlik daha fazladır (medyan 10.00). Çalışma hayatında, tükenmişlik yaşamadığını düşünenlerde, tükenmişlik daha fazla bulunmuştur (medyan 10.00). Kurumunda, karşılıklı güven ortamı içerisinde çalıştığına inanmayanlarda tükenmişlik daha fazladır (medyan 10.00). TSM'de çalışmışlık deneyimine göre ise $>9$ yıl çalışanlarda tükenmişlik daha fazladır (medyan 9.00). (Tablo 6) Maslach tükenmişlik ölçeği alt gruplarının memnuniyet anketindeki tatmin, 


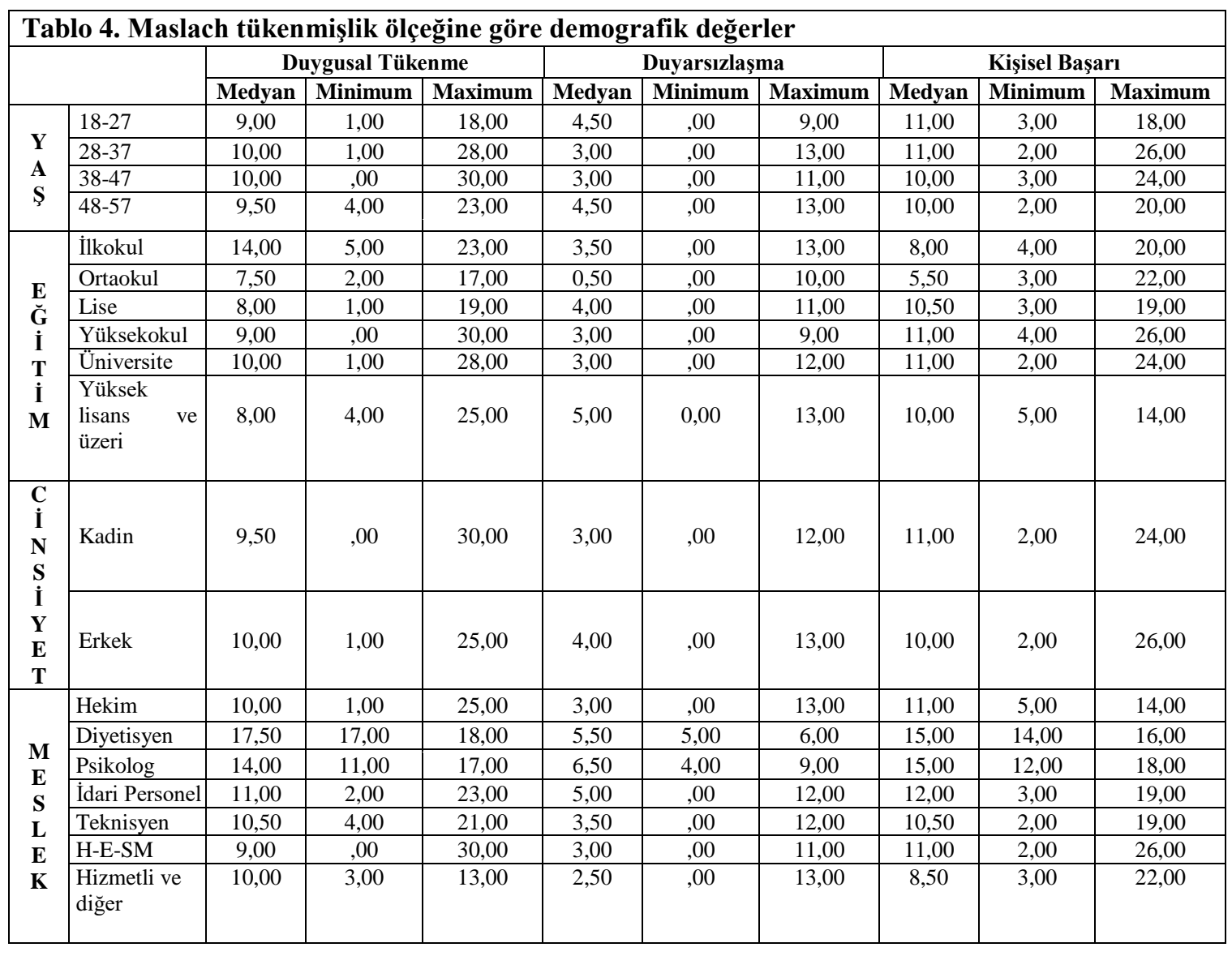

\begin{tabular}{|l|c|c|c|}
\hline \multicolumn{4}{|c|}{ Tablo 5. Demografik veriler ve aktif çalışmanın Maslach tükenmişlik ölçeğine etkisi* } \\
\cline { 2 - 4 } & Duygusal Tükenme & Duyarsızlaşma & Kişisel Başarı \\
\hline Yaş aralı̆̆ı & $\mathbf{p}$ & $\mathbf{p}$ & $\mathbf{p}$ \\
\hline Eğitim düzeyi & 0,87 & 0,10 & 0,91 \\
\hline Cinsiyet & 0,17 & 0,76 & 0,23 \\
\hline Meslek & 0,93 & 0,22 & 0,14 \\
\hline TSM'de çalışma süresi & 0,35 & 0,06 & 0,52 \\
\hline Aktif çalışma & 0,78 & 0,89 & 0,52 \\
\hline
\end{tabular}

*Ki-kare uygulanmıştır 


\begin{tabular}{|c|c|c|c|c|c|c|c|c|c|c|}
\hline & & \multicolumn{3}{|c|}{ Duygusal Tükenme } & \multicolumn{3}{|c|}{ Duyarsızlaşma } & \multicolumn{3}{|c|}{ Kişisel Başarı } \\
\hline & & $\begin{array}{c}\text { Medya } \\
\mathrm{n}\end{array}$ & Min & $\operatorname{Max}$ & Medyan & Min & $\operatorname{Max}$ & $\begin{array}{c}\text { Medy } \\
\text { an }\end{array}$ & Min & Max \\
\hline \multirow{5}{*}{$\begin{array}{l}\mathrm{Ne} \quad \text { kadar } \\
\text { süredir bu } \\
\text { kuruluşta } \\
\text { çalışyorsunu } \\
\text { z? }\end{array}$} & $\begin{array}{l}<1 \\
\text { yil } \\
\end{array}$ & 9,00 & 1,00 & 28,00 & 4,00 &, 00 & 13,00 & 10,00 & 3,00 & 26,00 \\
\hline & $\begin{array}{l}1-3 \\
\text { yil }\end{array}$ & 9,00 & 1,00 & 21,00 & 3,00 &, 00 & 10,00 & 11,00 & 5,00 & 20,00 \\
\hline & $\begin{array}{l}4-6 \\
\text { yil }\end{array}$ & 10,00 & 2,00 & 30,00 & 3,50 &, 00 & 11,00 & 12,00 & 2,00 & 24,00 \\
\hline & $\begin{array}{l}7-9 \\
\text { yil }\end{array}$ & 10,00 &, 00 & 20,00 & 4,00 &, 00 & 12,00 & 11,00 & 3,00 & 22,00 \\
\hline & $\begin{array}{l}>9 \\
\text { yil }\end{array}$ & 10,00 & 4,00 & 28,00 & 3,00 &, 00 & 13,00 & 9,00 & 2,00 & 20,00 \\
\hline \multirow{2}{*}{$\begin{array}{l}\text { Yaptığınız iş } \\
\text { sizi mesleki } \\
\text { olarak } \\
\text { tatmin ediyor } \\
\text { mu? }\end{array}$} & evet & 9,00 &, 00 & 25,00 & 3,00 & ,00 & 13,00 & 10,00 & 2,00 & 26,00 \\
\hline & $\begin{array}{l}\text { hay1 } \\
\mathrm{r}\end{array}$ & 11,00 & 1,00 & 30,00 & 4,00 &, 00 & 10,00 & 11,00 & 3,00 & 22,00 \\
\hline \multirow{2}{*}{$\begin{array}{l}\text { Çalışma } \\
\text { hayatıyla } \\
\text { ilgili } \\
\text { tükenmişlik } \\
\text { yaşadığınızı } \\
\text { düşünüyor } \\
\text { musunuz? }\end{array}$} & evet & 14,00 & 4,00 & 30,00 & 5,00 &, 00 & 13,00 & 11,50 & 3,00 & 24,00 \\
\hline & $\begin{array}{l}\text { hayl } \\
\mathrm{r}\end{array}$ & 8,00 &, 00 & 25,00 & 3,00 &, 00 & 13,00 & 10,00 & 2,00 & 26,00 \\
\hline \multirow{3}{*}{$\begin{array}{l}\text { Kurumunuzd } \\
\text { a karşıl1klı } \\
\text { güven ortamı } \\
\text { içerisinde } \\
\text { çalıştığınıza } \\
\text { inanıyor } \\
\text { musunuz? }\end{array}$} & evet & 8,00 &, 00 & 23,00 & 3,00 &, 00 & 13,00 & 10,00 & 2,00 & 26,00 \\
\hline & $\begin{array}{l}\text { hay1 } \\
\mathrm{r}\end{array}$ & 13,00 & 3,00 & 30,00 & 6,00 & ,00 & 13,00 & 11,50 & 4,00 & 22,00 \\
\hline & $\begin{array}{l}\text { yüze } \\
\text { ysel }\end{array}$ & 12,00 & 2,00 & 28,00 & 4,00 & ,00 & 11,00 & 12,00 & 3,00 & 24,00 \\
\hline
\end{tabular}

\begin{tabular}{|l|c|c|c|}
\hline \multicolumn{1}{|c|}{ Tablo 7. 'Tatmin, tükenmişlik hissi ve güven ortamı' sorularının Maslach tükenmişlik ölçeğine etkisi* } \\
\hline & Duygusal Tükenme & Duyarsızlaşma & Kişisel Başarı \\
\cline { 2 - 4 } & p değeri & p değeri & 0,03 \\
\hline $\begin{array}{l}\text { Yaptığınız iş sizi mesleki } \\
\text { olarak tatmin ediyor mu? }\end{array}$ & 0,03 & 0,37 & 0,03 \\
\hline $\begin{array}{l}\text { Çalışma hayatıyla ilgili } \\
\text { tükenmişlik yaşadığınızı } \\
\text { düşünüyor musunuz? }\end{array}$ & $<0,001$ & 0,08 & \\
\hline $\begin{array}{l}\text { Kurumunuzda karşılıklı guven } \\
\text { ortami icerisinde çalıstığınıza } \\
\text { inanıyor musunuz? }\end{array}$ & $<0,001$ & & \\
\hline
\end{tabular}

tükenmişlik hissi ve güven ortamı ile ilgili sorularla ilişkisi Tablo 7'de gösterilmiştir. Bu sorular, duygusal tükenme ve kişisel başarı alt ölçeklerine anlamlı düzeyde etki etmiştir. Duyarsızlaşma alt ölçeğine ise, sadece güven ortamını irdeleyen soru anlamlı düzeyde etki etmiştir.

\section{TARTIŞMA}

Araştırmamıza göre, anket uyguladığımız TSM'lerde tükenmişliğin düşük, memnuniyetin ise yüksek olduğu saptanmıştır. Amaçları ve görevleri düşünülünce, TSM'deki iş huzuru sağlık hizmet çıktısını olumlu yönde etkileyecektir.
Sağlık sektörü, veriyor olduğu hizmeti farklı kanatlardan sağlık alıcısına ulaştırmaktadır. Hastaneler, aile sağlığ 1 merkezleri ve TSM'ler bu senaryodaki ana rolü oynamaktadır. Sağlık sektöründe özveri ve yorgunluk kaçınılmazdır. Günlük rutin işler gerek mental gerekse de fiziki olarak çalışanı oldukça yıpratmaktadır. Hizmet verilen taraf, sağlığı korunan veya tedavi edilen kesimdir. Aldığı hizmetten memnun kalmak isteyen sağlık hizmet alıcısına yardım için sağlık hizmet vericisi bütün bilgi ve becerisiyle iş başındadır. $\mathrm{Bu}$ açıdan sağlık sunucusunun iş memnuniyeti ve tükenmişlik durumu hem kendisini hem de dışarıdaki vatandaşı etkileyecektir. 
Literatürde, hastane ve aile sağlığ merkezi çalışanlarında, hasta veya sağlık çalışanı ile ilgili psikolojik durumu değerlendiren bazı tez ve makale çalışmaları mevcuttur. Çalışmamız, TSM çalışanlarını hedef alan önemli bir araştırmadır.

Katılımcılarımız arasında geniş bir yaş dağılımında, TSM'de çalışabilecek neredeyse her statüde çalışan vardır. Bunlardan kadınlar, 38-47 yaş arasındakiler, H-E-SM en sik rastlanan grubu oluşturmaktayd1. Bir üniversite hastanesindeki, sağlık çalışanlarının tükenmişlik ve depresyon düzeylerini değerlendiren çalışmada, katılımcıların genellikle kadın ve 25-29 yaş aralığında olduğu görülmüştür. $\mathrm{Bu}$ katılımcılardan, kadınlarda erkeklere göre duygusal tükenme ve kişisel başarı alt ölçeklerinde tükenmişlik daha fazla saptanmıştır, yaş değerlendirmesinde ise fark görülmemiştir. Aynı çalışmada, meslekte çalışma süresi arttıkça, duygusal tükenmenin arttığı bulunmuştur. ${ }^{8}$ Taycan ve ark. da yaşın önemli bir değişken olduğunu vurgulamışlardır. ${ }^{9}$ Bizim araştırmamızda ise, demografik verilerin tükenmişliği yeterli etkilemediği saptanmıştır. Bazı çalışmalarda, bulgularımızla benzer şekilde, cinsiyetin tükenmişlik yönünden belirleyici olmadığı belirtilse de, ${ }^{10,11}$ kadınlarda tükenmişliğin daha yüksek olduğunu vurgulayan çalışmalar ağırlıktadır. ${ }^{12,13}$

Aras'ın çalışmasında en yoğun duygusal tükenmenin, 6 - 10 yıl deneyimlilerde olduğu, 20 yıldan fazla deneyimlilerde ise, duygusal tükenmenin azaldığ 1 ifade edilmiştir. ${ }^{14}$ Çalışmamızda, 4 yıl ve üzeri TSM deneyimi olan katılımcılarımızda duygusal tükenme, 9 yıldan fazla deneyimlilerde kişisel başarı skorlarının en kötü düzeylerde olduğu, duyarsızlaşmanın ise istatistiki anlam ifade etmeksizin yıllar ilerledikçe arttığ 1 görülmüştür. Akçalı'nın çalışmasına göre, hizmet süresi duyarsızlaşmayı artırmaktadır, ancak duyarsızlaşmayı etkileyen başka faktörlerin de olduğu düşünülmektedir. ${ }^{15}$

Ertuğrul'un çalışmasında, hastanede kötü yönetildiklerini düşünenlerin oranı $\% 26.3$, meslekte yeterli doyuma ulaşamadıklarını düşünenlerin oranı ise $\% 18.5$ idi. $^{8}$ Bizim çalışmamızda, kötü yönetildiklerini düşünenlerin oranı $\% 9,2$, meslekte yeterli doyuma ulaşamadıklarını düşünenlerin oranı ise \%40,9 idi. Anestezi ve dahili klinik çalışanlarında yapılan bir araştırmada ise, tükenmişlik alt ölçek skorları bizim çalışmamızdan daha yüksek hesaplanmıştır. ${ }^{16}$

Bulgularımıza göre; TSM çalışanı katılımcılarda, diğer bazı sağlık kuruluşlarında yapılan çalışmaların sonuçları ile kıyaslandığında memnuniyet durumunun daha yüksek, tükenmişliğin ise daha az olduğu görülmüştür. İş memnuniyetinin, tükenmişlikle kuvvetli bir ilişki içerisinde olduğu bilinmektedir. ${ }^{17}$ İdari birimlerin ve yöneticilerin çalışma desteği ve personelle kurduğu pozitif iletişim, iş yerindeki güven ortamını ve memnuniyeti arttırmaktadır. Benzer bir çıkarımı daha önce, laboratuar çalışanlarını hedefleyen bir çalışmada Lee ve ark. da saptamışlardır. ${ }^{18}$ Böyle bir ortamda çalışanlar, TSM'de çalışmaktan daha hoşnuttur, işe severek gelmektedir ve bu kişilerde tükenmişlik hissi daha azdır. Bulgularımıza göre, işinden tatmin olanların oranı çok yüksek değildir. Biz bu tatmin eksikliğini, iş yükü ve neden olduğu karşılıklı iletişim azlığ sonucu gelişen yöneticiler ve çalışanlar arası kopukluğa bağlıyoruz. Verilerimiz, günlük aktif çalışma yüzdesi ortalamasının \%70'ten fazla olduğunu göstermektedir. Yeniliklere açık olanlarda ise tükenmişlik daha düşük bulunmuştur, bu kişiler kişisel eğitimlerine daha çok önem vermektedir. Katılımcıların yaklaşık dörtte biri verilen eğitimleri yeterli bulmamaktadır, fakat bu oran tükenmişliğe anlamlı etki etmemiştir. Daha yüksek sayıda TSM ve personel katılımının sağlanacağı çalışmalarda eğitim yetersizliğinin tükenmişliği anlamlı oranda etkileyebileceğini düşünüyoruz.

Bu çalışmada, çalışanların kişilik ve sosyal özelliklerinin değerlendirilememiş olması en büyük eksiğimizdir. Yine, sadece beş TSM temsil edildiği için sonuçlar ülke genelindeki TSM'lere genellenemez. Ayrıca, TSM personellerinin meslek dağılımında dengesizlikler vardır, fakat TSM'lerin genel kadrolaşmasına bakıldığında hekim, diyetisyen, psikolog gibi meslek grubu çalışanlarının diğerlerinden çok daha az olduğu görülmektedir.

\section{SONUC}

$\mathrm{Bu}$ çalışma ile, anket uyguladığımız TSM çalışanlarında, diğer bazı sağlık kuruluşlarında çalışanlarla yapılan araştırmalara nazaran, memnuniyet durumunun daha yüksek, tükenmişliğin ise daha az olduğu görülmüştür. Çalışanların işlerini ve TSM'yi sevmelerinin yolunun iyi bir idare sistemi, hizmet içi eğitim ve destekleyici iletişimden geçebileceği kanaatine varılmıştır. Memnuniyet arttıkça tükenmişlik azalabilir. Personelin kendi işlerinde çalıştırılmaları iş tempolarını arttırabilir. Coğrafik değişiklikler TSM'lerin iş çeşitliliğini etkileyeceğinden farklı bölgelerden gelecek benzer çalışmalar da bu konuya 1 şık tutacaktır.

\section{Teșekkür}

Çalışmanın hazırlanması ve uygulanmasında desteklerini aldığımız, Sn. Psikolog Gül Deniz'e teşekkür ediyoruz. 


\section{KAYNAKLAR}

1. Resmi Gazete; Say1: 29258, Madde 4; 1 (n), 5 Şubat 2015.

2. Aydın Ş. İşgören devri, nedenleri ve sonuçları. editör: Cengiz Demir, konaklama işletmelerinde insan kaynakları yönetimi: ilkeler ve uygulamalar içinde (265-314), 1.Baskı. Ankara: Nobel Yayınlar1; 2005, s.283.

3. Fradelos E, Mpelegrinos S, Mparo Ch, Vassilopoulou Ch, Argyrou P, Tsironi M., et al. Burnout syndrome impacts on quality of life in nursing professionals: the contribution of perceived social support. Prog Health Sci 2014; 4(1): 102-9.

4. Sürgevil O. Çalışma hayatında tükenmişlik sendromu tükenmişlikle mücadele teknikleri. Ankara: Nobel Yayın Dağıtım; 2006. s.17-93.

5. Maslach C, Schaufeli WB, Leiter MP. Job burnout. Annu Rev Psychol 2001;52(1):397422 .

6. Memnuniyet anketleri uygulama rehberi yayımland.

https://kalite.saglik.gov.tr/index.php?lang=tr\& page $=46 \&$ newsCat $=1 \&$ newsID $=1250$. Erişim tarihi: 20.11.2015

7. Ergin, C. Doktor ve hemşirelerde tükenmişlik ve Maslach Tükenmişlik Ölçeğinin uyarlanması. VII. Ulusal Psikoloji Kongresi. Hacettepe Üniversitesi, Ankara; 1992 s. 143154.

8. Ertuğrul E. Üniversite uygulama ve araştırma hastanesinde çalışan hemşire, ebe, sağlık memuru ve acil tıp teknisyenlerinin tükenmişlik ve depresyon düzeyinin değerlendirilmesi. Yüksek Lisans Tezi. Zonguldak; 2010 s. 40-65.

9. Taycan O, Kutlu L, Çimen S, Aydın N. Bir üniversite hastanesinde çalışan hemşirelerde depresyon ve tükenmişlik düzeyinin sosyo- demografik özelliklerle ilişkisi. Anadolu Psikiyatri Dergisi 2006;7(2):100-108.

10. Kurçer M. Harran üniversitesi tıp fakültesi hekimlerinin iş doyumu ve tükenmişlik düzeyleri. Harran Univ Tip Fak Derg 2005;2(3):10-15.

11. Yaman H, Ungan M. Tükenmişlik, aile hekimliği asistan hekimleri üzerinde bir inceleme. Turk Psikol Derg 2002;17(49):3744.

12. Kocabıyık ZO, Çakıcı E. Sağlık çalışanlarında tükenmişlik ve iş doyumu. Anadolu Psikiyatri Dergisi 2008;9(3):132-138.

13. Ayraler A, Yavuz BG, Bakım B, Karamustafalığlu O. Diyaliz ünitesinde çalışan sağlık ekibinde tükenmişlik sendromu. JAREM 2011; 1: 52-56.

14. Aras Z. Birinci basamak sağlık kurumlarında çalışan hemşire ve ebelerin tükenmişlik durumları. Marmara Üniversitesi Sağlık Bilimleri Enstitüsü, Yüksek Lisans Tezi, İstanbul; 2006 s. 48.

15. Akçalı DT, Dayanır H, İlhan MN, Babacan A. İç Anadolu bölgesinde anesteziyoloji ve algoloji çalışanlarında tükenmişlik durumu. Ağr1 Dergisi 2010;22(2):79-85.

16. Aktaş E. Anestezi ve dâhili klinik çalışanlarında depresyon ve tükenmişlik sendromu açısından karşılaştırılması. Uzmanlık Tezi. Diyarbakır; 2013 s. 30-35.

17. Faragher EB, Cass M, Cooper CL. The relationship between job satisfaction and health: a meta-analysis. Occup Environ Med 2005; 62:105-12.

18. Lee MS, Lee MB, Liao SC, Chiang FT. Relationship between mental health and job satisfaction among employees in a medical center department of laboratory medicine. J Formos Med Assoc. 2009 Feb;108(2):146-54. 